\title{
EFETIVIDADE DA COMUNICAÇÃO DO PESSOAL DE ENFERMAGEM NA PASSAGEM DO PLANTAOO
}

\author{
Dilce Rizzo Jorge *
}

\section{INTRODUÇÃO}

A enfermagem enfrenta as mesmas dificuldades da comunicação que há em todos os setores da atividade humana. O problema da comunicação na área da enfermagem merece muito estudo, porque afeta o trabalho da enfermeira tanto de direção como de orientação e ensino. A enfermeira está constantemente recebendo e dando informações, porisso há necessidade de que ela aprenda a transmitir usando bom vocabulário, tanto profissional como não profissional; o seu modo de falar constrói sua imagem e influencia as suas relações com os demais.

A experiência tem mostrado que muitas dificuldades encontradas no trabalho de enfermagem, nas unidades, são causadas pela maneira como se comunicam as informações na passagem de plantão. O encontro do pessoal que entra com o que sai deveria ter, como primeira finalidade, transmitir informação sobre a situação dos pacientes, para a continuidade dos cuidados de enfermagem. Estas informações deveriam ser comunicadas pela enfermeira, ou líder do grupo. "Para que esta troca de plantão atinja a sua finaTidade é necessário que se dê atenção a duas áreas muito significativas: a filosofia do cuidado de enfermagem e o processo da comunicação."(5)

A passagem de plantão exige um relatório preciso do paciente e para isto é necessário pensar na filosofia da enfermagem. É o cuidado do paciente o centro de interesse da enfermagem? $\mathrm{E}$ o cuidado oio paciente mais do que simples tarefa realizada? São os pacientes observados e as soluções para as suas necessidades planejadas, executadas e avaliadas? $\mathrm{Na}$ passagem de plantão a condições dos pa-

* Docente da Escola de Enfermagem da USP. 
cientes devem ser completas, isto é dizer mais do que "dormiu bem a noite", ou "o paciente teve um bom dia". Será que o paciente teve realmente um bom dia? Será que ele não solicitou a atenção da enfermagem por acanhamento, ou será que suas necessidades não mudaram desde a última passagem de plantão? Quantas vezes o paciente está com determinada dieta para determinado exame, este é realizado e o paciente continua com a mesma dieta por muitos dias; ele não reclama e, na passagem de plantão, dizemos "o paciente está bem", "sem queixas" ou sem anormalidades.

A enfermeira chefe deve estar alerta para as atividades de administração e de enfermagem. A passagem de plantão deve focalizar o cuidado do paciente, que depende da filosofia do cuidado de enfermagem, e a informação deve ser correta, concisa e clara. $O$ conhecimento do processo da comunicação e de sua efetividade é de grande importância para a enfermeira; comunicação efetiva é a chave do êxito da coordenação de suas atividades.

A experiência de muitos anos somada à observação sistematizada de 10 passagens de plantão, em hospitais cujas unidades têm supervisora, enfermeira chefe e enfermeira, e a observação de 19 alunas em estágio de Administração aplicada à Enfermagem motivaram a realização deste trabalho, com o objetivo de alertar as chefias sobre importantes aspectos que devem ser analisados quanto à efetividade da comunicação entre os turnos que saem e que entram no hospital, 3 vezes no dia.

Antes de tecermos considerações sobre os fatores que influem na efetividade da comunicação e para clareza dos pontos que pretendemos dar ênfase, achamos interessante descrever algumas passagens de plantão, exatamente como foram observadas.

\section{SITUAÇÕES:}

\section{1) - Num determinado posto de enfermagem}

Os funcionários em pé, à volta do balcão. O posto está localizado em frente a dois elevadores, na encruzilhada de quatro corredores de grande movimento; é também ponto de encontro dos médicos, pois, lá se acham os prontuários dos pacientes e os telefones interno e externo. A comunicação é levada a efeito em meio a um grande barulho; mal se pode ouvir a pessoa que transmite e que, para agravar a situação, fala baixo. Enquanto a pessoa fala, abrese a porta dos elevadores com muito barulho (pois é ainda dos antigos) e o ascensorista grita "é aqui o andar"; vá à "esquerda"; 
"café", e coloca com grande barulho, fora do elevador, o pesado carrinho de café. Isto acontece umas 4 vezes nos minutos que durou a passagem de plantão. Os médicos entram e saem perguntando por exames e prontuários de pacientes. Numa das vezes havia seis médicos conversando no posto, um telefonando e vários pacientes transitando pelo corredor.

Quanto aos receptores, observamos grande dispersão de atenção a cada grito do ascensorista, a cada pessoa que passava no corredor; quanto às mensagens parecia que ninguém estava interessado, e só houve um despertar da atenção, quando chegou uma auxiliar dizendo "o 31 morreu!"

\section{2) - Em outro posto de enfermagem}

O posto está localizado em frente ao sanitário dos pacientes, ao lado de uma unidade de terapia intensiva. Foi observado o seguinte os funcionários em pé em volta da mesa; dois pacientes adultos e uma criança passando com a cadeira de rodas batendo nos funcionários e chamando a atenção de seis deles; outro paciente foi ao banheiro $\varepsilon$ três funcionários tiveram que se afastar para que ele passasse; cada "transeunte" do corredor atraia os olhares de todos os funcionários, e a atenção foi dispersada durante toda a transmissão das mensagens. Tudo isso, sem contar com grupinhos de funcionários conversando e rindo, e visitas de pacientes da terapia intensiva conversando no corredor com os médicos.

\section{3) - De leito em leito}

O procedimento é o seguinte: a enfermeira e o pessoal da manhã, acompanhados da auxiliar da noite, passam de leito em leito. Antes da passagem, já é feita a escala de serviço do pessoal da manhã.

Observou-se o seguinte: enquanto a pessoa que passa o plantão estava falando, perto de determinado leito, as que ouviam estavam com a atenção voltada para os outros leitos, esticando o pescoço para o movimento da outra enfermeira (a divisão é de vidro). Pareciam não estar interessadas em saber tudo sobre todos, a não ser dos que estariam sob a sua responsabilidade no plantão, pois, eram dadas oralmente muitas informações sobre um grande número de pacientes e que já constavam de anotações no prontuário de cada um deles.

Nesta situação também observamos grande dispersão da atenção; na realidade ninguém poderá reter tudo de todos os pacientes que são em número de 72. 
4) - Em sala fechada

Os funcionários todos sentados numa sala pequena e abafada, sem ruído ou interferência. Os receptores de início estavam atentos, mas dispersaram para outros assuntos por falta de coordenação da enfermeira (isto geralmente acontece em ambiente fechado). A enfermeira chegou 10 minutos atrazada, e a impaciência dos que esperavam deu a impressão de desagrado e contribuiu para a dispersão da atenção e conversas pararelas.

\section{5) - Na Emergência}

A comunicação foi nos seguintes termos:

- “O n.o ... está mal, parece que vai, e não adianta fazer nada".

- O n. ... também não adianta fazer nada".

— "O n.o ... o médico disse que vai embora, com esse você também não tem nada que fazer".

— "O n.o ... este, sim, precisa de cuidados e então o que ouve, anota somente deste paciente".

Poderíamos descrever muitas outras situações, mas estas já đão a idéia de como tem sido a comunicação nesse importante trabalho da enfermagem.

FATORES QUE INTERFEREM NA EFETIVIDADE DA COMUNICAÇÃO E QUE FORAM IDENTIFICADOS NAS PASSAGENS DE PLANTÃO, ATRAVÉS DA EXPERIÊNCIA E DAS OBSERVAÇÕES SISTEMATIZADAS

Toda comunicação tem um objetivo: produzir efeito consumatório ou instrumental. Efeito consumatório é aquele em que o receptor se sente informado e satisfeito. Efeito instrumental é aquele cuja informação é usada para realização de outro fim: servir de instrumento. Qualquer mensagem pode ter muitos objetivos, alguns altamente consumatórios e outros altamente instrumentais. $\mathrm{Na}$ passagem de plantão, os objetivos são tanto consumatórios como instrumentais; na grande maioria, instrumentais, porque dizem respeito à atitude da equipe para com os pacientes e à execução de cuiđados aos pacientes.

O processo da comunicação realiza-se através dos seguintes elementos:

1 - Fonte - que pode ser uma pessoa ou um grupo de pessoas com o objetivo de transmitir uma mensagem. 
2 - Mensagem - é a expressão do objetivo da fonte.

3 - Canal - é o intermediário, isto é, o condutor da mensagem.

4 - Receptor - pode ser uma pessoa ou um grupo de pessoas que receberão a mensagem.

Cada elemento do processo apresenta características que influem na efetividade da comunicação. A seguir, estes elementos serão analisados de acordo com o que foi observado.

\section{1 - Fatores da fonte e do receptor}

A comunicação humana depende da experiência, em comum, e da significação, em comum, dos símbolos entre estes dois elementos. O relacionamento fonte-receptor, desde que envolve pessoas, sistemas sensoriais das pessoas, nos dá idéia da sua complexidade, porque a percepção humana é um fenômeno puramente individual. Se a comunicação procura modificar as imagens dentro de nossas mentes, teremos de levar em consideração que, embora os homens vivam no mesmo mundo, pensam e sentem em mundos diferentes pessoais e individuais. A percepção é sempre pessoal e cada experiência é estrutura de acordo com os nossos termos. As informações não possuem uma lógica própria, pois não resultam das mesmas percepções e conhecimentos; serão sempre percebidas e interpretadas em termos das necessidades, emoções, personalidade e padrões cognitivos individuais, que trazem obstáculos originários de preconceitos, educação, hereditariedade, meio, estado físico, emocional, inclusive os relativos à atenção visual, auditiva, capacidade de concentração etc. Por tudo isso, a eficiência da forma da mensagem na comunicação humana é muito variável e pode-se concluir que: "certos tipos de comunicação, sob certos tipos de assuntos trazidos à consideração de certos tipos de pessoas, sob certos tipos de condições, podem ter certos tipos de efeitos" (8).

Há quatro fatores da fonte e do receptor que diminuem a eficiência da comunicação.

\section{1 - Habilidades comunicativas}

Se a fonte não tiver habilidades comunicativas, não saberá transmitir a mensagem; se o receptor também não as tiver, não terá capacidade de receber a mensagem.

Em nossa observação, verificamos o seguinte: a grande maioria que passa o plantão não tem habilidades comunicativas; fala baixo e inexpressivelmente, possue pouco conhecimento, além de usar lin- 
guagem inadequada. Os que ouvem também não a têm, e por isso há interpretações diferentes das mensagens. Verificamos que há sempre mal entendidos com relação às informações de pacientes.

\section{2 - As atitudes da fonte $e$ do receptor}

As atitudes da fonte para com o receptor e vice-versa afetam a comunicação; quando os receptores percebem o interesse da fonte, mostram-se mais atentos; do mesmo modo, se os receptores não tiverem interesse pela mensagem, terão atitudes diferentes para com a fonte.

Quanto à atitude da fonte na passagem de plantão, observamos que geralmente é apática, desinteressada, parecendo ter pressa em sair. Quanto ao receptor, notamos grande dispersão da atenção, algumas vezes completo desintesesse pela mensagem, dando a impressão de não serem os mesmos os interesses da fonte e do receptor. Notou-se mudança de atitude do receptor quando a informação era de interesse pessoal, como: "dia x é feriado", "preciso da lista de pedido de folgas", ou outra comunicação administrativa do pessoal em geral. Esta atitude confirma que ouvimos melhor o que nos interessa.

\section{3 - O nivel de conhecimento da fonte e do receptor}

O nível de conhecimento da fonte afeta a mensagem, porque ninguém é capaz de comunicar bem, se não tiver conhecimento bastante do que vai expor. Se o receptor não conhecer o código, também não entenderá a mensagem.

Em nossa observação, este foi um dos pontos marcantes, porque a fonte quase sempre não é a pessoa de maior conhecimento e que poderia se expressar melhor o que se passa no seu plantão. Na grande maioria das vezes, é o auxiliar de enfermagem que informa sobre os pacientes, isto é, quem dá as informações mais importantes; algumas vezes é o atendente e raramente é a enfermeira.

\section{$1.4-$ A posição sócio-cultural no sistema}

importante para a boa comunicação as funções que a fonte desempenha e o prestígio que goza no sistema. Quanto ao receptor, o status social, os demais componentes do grupo, suas formas habituais de conduta afetam os modos pelos quais recebe e interpreta a mensagem. É de grande importância o fator hierárquico entre 0 transmissor e o receptor, considerando-se que a receptividade da. 
mensagem depende fundamentalmente da autoridade da fonte. Nas passagens de plantão, como foi visto no item acima, não é a pessoa do nível mais alto da hierarquia que comunica as informações.

\section{2 - Fatores da mensagem}

Além das experiências em comum e da significação em comum dos símbolos entre fonte e receptor, a comunicação humana depende da atenção à mensagem.

A mensagem é a expressão do objetivo da fonte; pode ser transmitida de várias formas. A forma usada na passagem de plantão é a oral. As mensagens sofrem alterações no momento da emissão, durante a transmissão e na recepção. A mensagem transmitida verbalmente tem vantagens e desvantagens e é influenciada por muitos fatores, tais como tom da voz, expressão facial, da mão, hora e circunstância. Tudo isso dá uma série de significados que enriquecem a mensagem mas, em contra partida, abrem possibilidades para mil interpretações. Dá oportunidade à fonte de esclàrecer a exatidão da mensagem, quando não é bem compreendida pelo receptor, assim como de verificar imediatamente se o destinatário aceita ou rejeita a mensagem.

A mensagem sofre filtrações e distorções. Filtra-se tanto a informação que se transmite como a que se recebe.

Em qualquer informação, o receptor ouve somente a parte que interessa e omite $o$ resto, e a fonte transmite apenas a parte que interessa a ela, que lhe parece mais útil e eficaz. O próximo receptor que irá receber a mensagem fará o mesmo e assim haverá sucessivamente uma degradação permanente da informação por filtragem. Embora pensando que a mensagem tenha sido transmitida corretamente, na verdade foi transformada. Dizemos que a mensagem foi filtrada porque eliminamos elementos em função das características de nossa realidade. Cada um que passa distorce sua forma e, ao atingir o receptor, já sofreu uma considerável distorção.

É comum, nas passagens de plantão, diálogos como estes:

1) - "Auxiliar - a dentadura do sr. $\mathrm{X}$ desapareceu.

Enfermeira - ontem, na pasagem de plantão eu falei que ele tinha dentadura e que cuidassem.

Auxiliar — Eu falei também para a $Y$ mas não sei o que aconteceu."

2) - "Enfermeira - Ontem, na passagem de plantão, eu disse que o procedimento com relação ao paciente $\mathrm{X}$, seria...

Auxiliar - quando passei o plantão ao auxiliar da noite, falei a ele como a senhora me falou. 
Enfermeira" - mas foi feito diferente e saiu tudo errado.

Auxiliar - eu não sei, transmiti exatamente como me foi falado".

Chamando a atenção do auxiliar da noite, este disse: "mandei o atendente fazer exatamente como me falaram na passagem de plantão".

O que aconteceu com a mensagem? Passou por três pessoas e cada uma delas a filtrou e houve distorsão da mesma. Para todos €stava correta e foi transmitida e executada como cada um entendeu. Quanto maior for o número de pessoas por que passa a mensagem, maior será a distorção. O provérbio popular "quem conta um conto acrescenta um ponto", é uma realidade. Um caso clássico de distorção é o do Capitão que mandou a seguinte mensagem: "Reunir os soldados no pátio, se houver bom tempo para lhes mostrar um eclipse e lhes explicar o fenômeno; as explicações serão dadas no salão interno".

A mensagem vai do Capitão ao Tenente, do Tenente ao SubOficial, do Sub-Oficial ao Sargento, do Sargento ao Cabo, chegando aos soldados assim: "amanhã, haverá um eclipse no pátio por ordem do Capitão; se chover o Capitão fará o eclipse no salão interno”. (7)

Casos como este não podem acontecer na enfermagem; é necessário mudar a forma de comunicação, porque a enfermagem lida com pessoas doentes e qualquer erro, por menor que seja, pode ser fatal. É preciso muito cuidado com estas mensagens, porque a comunicação oral envolve muitas palavras e a compreensão da mensagem é influenciada por diversos fatores, entre eles, a atenção, a audição e a linguagem.

\section{1 - Atenção}

A comunicação está na dependência inicial da atenção. Atender é concentrar a atividade, é preparar-se para perceber certo objeto ou fazer alguma coisa. Atrair e manter a atenção é um sério problema da comunicação humana. O ruído forte chama a atenção e leva vantagem sobre o murmúrio. (8)

Nas passagens de plantão observadas, a atenção foi dispersada pelo ruído em todas as situações. Não notamos esforço por parte da líder em atrair e manter a atenção dos funcionários para as mensagens.

\section{$2.2-$ Audição}

"É preciso ouvir para compreender; nossa resposta dependerá da compreensão do que ouvimos. Ouvir é difícil, é mais do que simples processo, é uma atitude voluntária. Ouvimos melhor quando 
nossa atenção é estimulada e ouviremos melhor sempre que precisamos compreender assuntos de interesse; nossa curiosidade for despertada; alguém se referir a qualquer assunto que nos afete pessoalmente".

Quanto aos fatores mentais da audição que interferem na recepção da mensagem observamos nas passagens de plantão: indiferença da maioria, impaciência de alguns e preocupação de poucos: num esforço para captar a mensagem.

\section{3 - Linguagem}

A comunicação verbal, forma usada para transmitir as mensagens na passagem de plantão, apresenta vários obstáculos que influem muito na recepção da mesma. Entre eles destacamos: expressões capazes de despertar antagonismos, expressões que demonstram dúvida quanto à inteligência do ouvinte, expressões que se repetem sucessivamente, certas exclamações do ouvinte interrompem a exposição verbal da.fonte, palavras e expressões excessivamente familiares, palavras sérias ditas em tom jocoso, palavras que fazem referência a defeitos ou características físicas, expressões de gíria em geral, vícios de linguagem e os defeitos decorrentes do desconhecimento da pronúncia, os expositores pernósticos, os tímidos, os falastrões, os que gesticulam demais, os que fazem trejetos faciais etc. A palavra EU também arrisca-se a ser uma grande barreira verbal.

Considerando todos esses fatores, a mensagem deve ser a mais clara e simples possível, evitando-se os obstáculos orais que dão margem a interpretações diversas.

Quanto às expressões incorretas identificadas e que constituem obstáculos à efetividade da comunicação, teríamos uma grande lista que achamos desnecessário citar, pois são sobejamente conhecidas no hospital. Apenas para ilustrar:

- o n. . .. morreu; ontem ele teve um "troço" e disseram que era piripaque, coitado!"

- "o paciente cuspiu no chão, era uma porcaria"

- "os paciente foi"

- "o paciente dormiu mais ou menos"

— "o paciente está razoável"

-_ "os poblema"

- "fezes diarréicas amolecidas"

- "este paciente é uma chato"

- "o paciente vai pifar"

— “o n." ... não está legal"

— "o n. .. está mal, parece que vai, não adianta fazer nada" 
A seguinte mensagem é um exemplo de forma incorreta de transmissão, cuja efetividade da comunicação é prejudicada. A enfermeira, chamando a atenção dos funcionários quanto às anotações no relatório de enfermagem que vinham sendo feitas somente no fim do período:

"Tenho avisado sempre da necessidade das anotações imediatas, como diurese, peso, e de mais grave com o doente; e as coisas de menos importância, pode deixar para marcar depois".

Esta mensagem não foi clara, não definiu o que é "de mais grave" e de "menos importância"; os ouvintes podem ter critérios diferentes quanto a "mais grave" e "de menos importância". Esta mensagem foi dada a pessoas de diversas categorias; a enfermeira não pensou nisso, pensou que estivesse falando com pessoal de seu nível de conhecimento, com relação ao estado dos pacientes.

Verificamos que todos esses fatos já considerados influem nas interpretações erradas; que resultam, em confusão. Ex. com a substituição do nome do paciente pelo número do leito, o paciente pode ser confundido com outro; a alta pode ser dada ao paciente errado; o jejum pode ser quebrado e um cem número de coisas que acontecem, que nos são muito familiares no hospital. No entanto, quem transmite a mensagem está consciente de que a transmitiu muito bem e de que todos os que a ouviram entenderam exatamente como foi transmitida. Isto não acontece na realidade.

Quanto à maneira de falar, das pessoas a quem tivemos oportunidade de ouvir, muitas podem ser identificadas com as citadas por Penteado (8), que assim se expressa:

"Há muitas maneiras de falar, há os que falam aos arrancos, como se as palavras fossem extraídas à força do aparelho fonador; há os que, ao falar, sobem e descem as modulações com a versatilidade de certas músicas modernas, onde há excesso de dissonância € quase nenhuma harmonia; há os que embrulham as palavras de maneira a torná-las apenas sons sem significação; há os que falam mantendo a boca quase fechada, e as palavras conseguem escapar de entre os lábios furtivas como fugitivos de uma prisão; há os que falam muito baixo ou muito alto; há os que falam tão devagar que levam os ouvintes à sonolência, e há os que falam tão depressa, que acabamos impossibilitados de distinguir palavras nas cascatas de sons que se sucedem com a fúria das correduras dos rios, há os que têm a voz fria, grossa, rouca, estridente, brutal e infantil".

Nas passagens de plantão, além de muitas dessas maneiras, predominou a voz baixa 


\section{3 - Fatores do Canal}

O canal é o intermediário que leva a mensagem. Na passagem de plantão o canal é o ar, o meio ambiente. Para que a mensagem seja bem transmitida é necessário que o canal seja isento de interferências. $O$ ruído e as condições do meio ambiente são os fatores mais comuns que reduzem a efetividade do processo comunicativo.

\section{$3.1-R u i d o$}

O ruído reduz a efetividade da comunicação, porque distrai a atenção e prejudica a audição da mensagem. Nas passagens de plantão, o ruído foi fator constante em todas as situações observadas; foram identificadas as seguintes fontes de ruídos:

- conversa entre os funcionários;

- barulho dos elevadores, macas e carrinhos;

- movimento dos pacientes;

- funcionários que chegam atrasados;

- campainhas chamando;

-. telefone;

- entrada e saída de funcionários e médicos;

- conversa dos médicos.

O ruído interferiu no canal, impedindo que as mensagens fossem bem transmitidas. $O$ resultado apresentado pelas alunas, quanto à retenção das mensagens, foram os seguintes:

- retivemos pouco, o movimento de pessoas impediu que ouvíssemos bem;

- o barulho impediu que ouvíssemos a voz baixa do transmissor;

- retivemos quase nada, por causa do barulho, movimento de pessoas e voz baixa do transmissor.

\section{2 - O meio ambiente}

O meio ambiente onde são passados os plantões, conforme já foi mostrado nas sicuações apresentadas no início de trabalho, não é nada recomendável. O ambiente deve ser agradável, calmo, com as pessoas acomodadas confortavelmente, dando condições para troca de idéias a respeito do estado dos pacientes; deve ser num recanto dedicado à conversa, onde se pode ouvir melhor, sem interrupções e sem ruidos. 
O ambiente favorável ajuda a audição, por conseguinte maior atenção resultando em melhor compreensão das mensagens e menos problemas de intepretações a serem resolvidos pelo chefe.

Pelo exposto, verifica-se que a efetividade da comunicação na passagem de plantão é prejudicada pelos graves defeitos em todos os elementos do processo comunicativo, isto é, na fonte, no receptor, na mensagem e no canal.

\section{OBSERVAÇÕES DAS ESTUDANTES}

As seguintes observações das estudantes, em estágio de "Administração aplicada à enfermagem", confirmam o que foi analisado:

- "Nem sempre estão presentes todos os funcionários; dos presentes a maioria não presta atenção; o local não é apropriado".

- "Há muitas informações incompletas como: "um paciente que está com dieta hipoproteica comeu o ovo cozido do outro paciente".

- "As informações sobre pacientes graves não são detalhadas".

- "Do modo como é realizada a passagem de plantão, não existem condições para que se possa atingir seus objetivos; os problemas dos pacientes deveriam ser comentados mais dinamicamente e não apenas lendo o relatório; deveria ser em outro ambiente para que a atenção não fosse desviada".

- "Da maneira como é realizada, torna-se dispersiva e sem grande interesse por parte dos funcionários; muito barulho, pressa em ir embora, atraso de funcionários, voz baixa e informações insuficientes".

- "As passagem de plantão deveria ser um trabalho de equipe com todo o pessoal analisando as necessidades do paciente; em local privativo e não no posto onde os pacientes passam a todo instante; deveria ficar um funcionário encarregado dos pacientes, evitando que os demais saíssem, correndo para atendê-los; os funcionários que chegam atrasados distraem a atenção dos outros e outras vezes nem assistem à passagem e começam o serviço sem terem ouvido nada sobre os pacientes".

- "As informações sobre os pacientes são muito superficiais e rápidas, muitas vezes comunicadas pelas atendentes; não é dada ênfase aos cuidados especiais aos pacientes e não notei participação ativa da enfermeira quanto a levantamento de problemas, interrogando a pessoa que passa o plantão e também avaliando a veracidade das informações; simplesmente aceita os dados fornecidos, nada acrescentando". 


\section{CONCLUSÃO}

Do estudo realizado, concluimos que a passagem de plantão da enfermagem, da forma como ve msendo feita, não está baseada na filosofia da enfermagem, cujo centro de todas as atividades é o paciente. Apresenta muitos defeitos em todos os elementos do processo comunicativo. Em todas as situações observadas, a atenção foi dispersada pelo ruído, pelas deficientes habilidades comunicativas tanto na fonte como do receptor, além dos locais impróprios para transmissões. A linguagem inadequada é também fator marcante que soa muito mal aos ouvidos, principalmente das estudantes, em periodo de formação profisisonal.

Na forma como vem sendo realizada, pode-se até deduzir que a finalidade principal é o encontro dos funcionários dos dois turnos, que sempre têm uma conversinha particular logo após a passagem de plantão, principalmente os que fazem comércio às escondidas no hospital, assim como para a constatação da presença e distribuição da escala de serviço.

\section{SUGESTÃO}

O Serviço de Enfermagem, responsável pelo treinamento, oriertação, educação contínua dos funcionários de sua equipe, revisão e avaliação contínua das rotinas, deveria dar atenção especial à revisão da rotina de passagem de plantão, que vem sendo realizada da mesma forma há muitos anos. É necessário educar a equipe de enfermagem para que tome consciência da importância desse trabalho, que deverá ser baseado na filosofia da enfermagem, e que é realizado sem o conhecimento dos fatores que influem na eficiência da comunicação. Muitas dificuldades e perda de tempo poderão ser evitados se as chefias se conscientizarem de que há grande necessidade de revisão dessa rotina, para que realmente haja comunicação efetiva na passagem de plantão.

\section{$V$ - BIBLIOGRAFIA}

1 - AZEVEDO, M. N. de - A reconstrução humana. Rio de Janeiro, Civilização Brasileira, 1971.

2 - BERLO, D. K. - O pracesso da comunicação. Rio de Janeiro, USAID, 1963.

3 - CHERRY, C. - A comunicação humana. São Paulo, Ed. U.S.P., 1971.

4 - COHN, G. - Comunicação e indústria cultural. Sáo Paulo, Ed. U.S.P., 1971. 
5 - FEELEY, E. M. - The challenge of inter-shift reporting. Supervy. Nurse 1 (2), 43-45, 1973.

6 - KRIEGHBAUM, H. - A ciência e os meios de comunicação de massa. Rio de Janeiro, Edições Correio da Manhã, 1970.

7 - PATERnOSTRO, J. N. - Psicologia aplicada à empresa e à administração: Programa, bibliografia e resumo de aulas ministradas no curso de Administração Hospitalar da Faculdade de Saúde Pública da U.S.P. São Paulo, 1972.

8 - PENTEADO, J. R. W. - A técnica da comunicação humana. São Paulo, Pioneira, 1964.

9 - REDFIELD, C. E. - Comunicação administrativa. Rio de Janeiro, Fundação Getúlio Vargas, 1966, 